\title{
Characterization of Aluminum(III) Complexes in Coal Organic Matter
}

\author{
Pavel Straka \\ Department of Materials Structure and Properties, Institute of Rock Structure and Mechanics, v.v.i., The Czech \\ Academy of Sciences, Prague, Czech Republic \\ Email: straka@irsm.cas.cz
}

Received 18 February 2016; accepted 19 April 2016; published 22 April 2016

Copyright (C) 2016 by author and Scientific Research Publishing Inc.

This work is licensed under the Creative Commons Attribution International License (CC BY). http://creativecommons.org/licenses/by/4.0/

c) (i) Open Access

\section{Abstract}

For geochemical purposes, complex aluminum compounds in coal organic matter in different types of coal were identified by solid state nuclear magnetic resonance measurements of ${ }^{27} \mathrm{Al}$. Low ash samples of anthracites, bituminous coals and altered coals from the Czech Republic, Russia, Ukraine, China and Australia were tested; further, low ash lignite and xylite from the Czech Republic and gagatite from Poland were analyzed. In acquired ${ }^{27} \mathrm{Al}$ MAS NMR spectra, two significant peaks at chemical shifts were recorded, at 3.5 - 4 and 13.5 - $15 \mathrm{ppm}$. It was found that the significant peak at chemical shift at $3.5-4$ ppm in spectra of bituminous coals, lignite, gagatite and a thermally weakly altered coal corresponds to that obtained for triaquo-hydroxo-diphenoxidoAluminum(III) complex. The existence of triaquo-triphenoxido-Aluminum(III) complex in the spectra of anthracites, some bituminous coals and another thermally altered coal can be approved by the chemical shift at 13.5 - $15 \mathrm{ppm}$. These findings indicate that at least two different Al complexes were identified in coal organic matter. Further it was found that these complexes are concentrated in vitrinite fraction (alicyclic-aromatic part of coal), notably in collotelinite (gelified and homogenous vitrinite constituent). Ways of Al complexes formation in coal are suggested and their thermal stability is discussed.

\section{Keywords}

Aluminum, Complex, ${ }^{27}$ Al MAS NMR, Coal, Lignite, Altered Coal

\section{Introduction}

Complexes in coal are among the least investigated compounds, despite the fact that their study could lead to the discovery of entirely new complex compounds and to an increase in knowledge about coal composition, espe- 
cially for geochemical purposes. In our case, attention was paid to $\mathrm{Al}$ complexes, since $\mathrm{Al}$ is capable of forming strong complexes and its concentration in bituminous coal and lignite is often quite high $(0.5 \%-1 \%)$. Until now, attention has been paid to $\mathrm{Al}$ in coal clays, e.g. in the works Howarth et al. [1]; Komarneni [2]; Thompson and Botto [3], but only exceptionally [4] an investigation of $\mathrm{Al}$ in coal organic matter has been carried out.

$\mathrm{Al}$ can create a range of complexes with inorganic ligands, compounds with hydrocarbons [5], undefined complexes with alcohol, ether and ketone groups [6], compounds of a complex nature such as Al phenoxide and Al salicylate [7], as well as complexes of organic acids such as phenolic, chlorogenic, gallic, citric, malic and oxalic [8]. Further, $\mathrm{OH}-\mathrm{Al}$-humate and $\mathrm{OH}-\mathrm{Al}$-humate-montmorillonite complexes have been prepared and conditions for their formation reported [9]. An extensive overview of the forms of the occurrence of elements in coal [10] reports additional unspecified complex compounds in the case of $\mathrm{Be}, \mathrm{Cu}, \mathrm{Ge}, \mathrm{U}$ and $\mathrm{W}$, as well as possible porphyrin complexes with a central atom $\mathrm{Ga}, \mathrm{Mn}, \mathrm{Ni}$ and $\mathrm{V}$. No examples of the occurrence of $\mathrm{Al} \mathrm{com-}$ plexes were discussed, although mellite, present in coal, and its likely association with $\mathrm{Al}$ was mentioned. This association was further investigated; according to Klika and Kolomazník [11], Al is one of the elements with significant affinity for organic matter in coal. The occurrence of $\mathrm{Al}$ complexes with organic ligands is therefore likely. In this connection, the question of bonding arises. Bonding between humic acids and $\mathrm{Al}$ in clays was studied with salicylic acid as a model compound [7]. The mechanisms of bonding and the linkages between salicylate anions and $\mathrm{Al}^{3+}$ octahedra at illite clay edges were therefore investigated using Fourier transform infrared spectroscopy; molecular orbital calculations were performed, too. On this basis, the authors suggested that covalent $\mathrm{Al}-\mathrm{O}-\mathrm{C}$ linkages form between salicylate anions and $\mathrm{Al}^{3+}$ octahedra. In the context of humic substance formation, the covalent $\mathrm{Al}-\mathrm{O}-\mathrm{C}$ linkages in the $\mathrm{Al}$ intermediate complexes were also suggested as an explanation for the catalysis by hydroxyl-aluminosilicate ions during catechol humification [12]. Jehlička and Edwards [13] studied organic components in the geological record using Raman spectroscopy and obtained information about the organic environment of $\mathrm{Al}^{3+}$ ions. Furthermore, FTIR spectroscopy was used for an investigation of the ligands in hexa- and tetra-coordinated $\mathrm{Al}$ in altered coal and low temperature coal ash [14] [15]. Thompson and Botto [3] conducted MAS NMR experiments on coal and concluded that correlations of tetrahedral Al content with coal rank arise assuming that contribution from organo-chelated $\mathrm{Al}$ species is taken into account.

In terms of methods, ${ }^{27} \mathrm{Al}$ magic angle spinning nuclear magnetic resonance $\left({ }^{27} \mathrm{Al}\right.$ MAS NMR) spectroscopy is sensitive to the local environment of central $\mathrm{Al}$ atoms [16] [17]. When dealing with quadrupolar nuclei, such as ${ }^{27} \mathrm{Al}$, the peak position does not correspond to the true isotropic chemical shift, due to second-order quadrupole effect. To get the true isotropic chemical shift, it would be necessary to use multiple-field NMR measurements, lineshape fitting or other more complex methods [18]-[20]. Only if the quadrupole coupling is negligible, the peak position can be identified with the isotropic chemical shift. Therefore, in our case, the significant peaks at chemical shifts were observed (peak shifts). Local $\mathrm{Al}$ environments had been extensively studied using ${ }^{27} \mathrm{Al}$ MAS NMR spectroscopy [1] [21]-[23], but the method had not been reported as being suitable for the identification of Al complexes in coal until quite recently, in the work [24]. In this work, 2-methoxyethanol extracts obtained from the Ostrava-Karviná (Czech Rep.) bituminous coal and from the North Bohemian (Czech Rep.) lignite were investigated. It was found that the significant peak at chemical shift at $14-15 \mathrm{ppm}$ corresponds to that obtained for a phenoxido-Aluminum(III) complex with Al hexa-coordinated with oxygen (14.2 ppm). The work [3] shows that ${ }^{27} \mathrm{Al}$ MAS NMR method is applicable for identification of Al complexes in coal, but mineralogical analysis is necessary. From this work it follows that only low ash samples of coal can be used for $\mathrm{Al}$ complexes investigations, because such samples contain large amount of organic matter of coal and, probably, also larger amounts of $\mathrm{Al}$ of complexes with organic ligands are present.

The aim of this work is to identify and characterize Al complexes in coal (anthracite, bituminous coal, altered coal, lignite and xylite) and assess their thermal stability, both for solving some geochemical issues and outstanding questions of temperature conditions of coal formation [25]. The essence is that, probably, the relevant Al complexes are thermally not very stable; therefore, coals containing them were formed under very mild thermal conditions - otherwise the Al complexes decomposed or transformed.

For such a study, a choice of standard $\mathrm{Al}$ compounds and complexes is important. Aluminum phenoxide was chosen as a stable compound containing phenoxide anions and with a possible complex structure [26]; other reference complexes were selected on the basis of work by Nagata et al. [8], Chen et al. [27] and Straka [15].

Compared with an organo-clay complexes [28], the thermal stability of other Al complexes has been studied very few. Zachariáš and Pešek [29] mentioned the stability of Al complexes considered in coal up to temperature of $85^{\circ} \mathrm{C}-5^{\circ} \mathrm{C}$; Rosca et al. [30] found the thermal stability of some $\mathrm{Al}$ complexes with $\beta$-diketones mainly 
up to $91^{\circ} \mathrm{C}-155^{\circ} \mathrm{C}$ (at a heating rate $5^{\circ} \mathrm{C} / \mathrm{min}$ ). In our experience the $\mathrm{Al}$ complexes with phenoxide ligands begin to decompose at temperatures $105^{\circ} \mathrm{C}-125^{\circ} \mathrm{C}$. It can be estimated that their thermal stability is not very high. Therefore, an appropriate attention was paid to this issue.

In this work, possibilities of formation of $\mathrm{Al}$ complexes in coal are discussed, too. On the basis of the data presented by Bouška [31], Sinkó et al. [32], Ruiz-Hitzky et al. [33] and Thomas [34], taking into account the behavior of $\mathrm{Al}$ in coal, the occurrence of kaolinite as a possible source of $\mathrm{Al}$ in coal complexes, clay-organic interactions and the relationship of the structure of kaolinite and gibbsite with the structure of $\mathrm{Al}$ complexes in coal, the possibilities of their formation are outlined.

\section{Materials and Methods}

\subsection{Materials}

\subsubsection{Coals}

For measurements, air-dried powdered low ash coal samples with an ash content up to 4 wt\% (1.51 - 4.10 wt\%, see below) were selected. Bituminous coals from the Czech Republic (Upper Silesian Basin and Central Bohemian Basin), Australia (Queensland, Peak Downs), and China (Shanxi Province, An Tai Bao open pit mine) were examined along with lignite from the Czech Republic (Northern Bohemian Basin). Further, xylite from the Cheb Basin (Czech Republic), anthracites from the Czech Republic, Russia and Ukraine, and the thermally altered coals from Upper Silesian and Central Bohemian basins were tested.

\subsubsection{Coal Fractions}

From three coals from Upper Silesian Basin (Czech Rep.) the fractions with low ash content were prepared. Those fractions from Dukla coal $\left(1.27-1.33 \mathrm{~g} / \mathrm{cm}^{3}\right)$, 9.květen coal $\left(1.24-1.29 \mathrm{~g} / \mathrm{cm}^{3}\right)$ and Staříc coal $(<1.30$ $\mathrm{g} / \mathrm{cm}^{3}$ ) were separated with a sink-float method using xylene/CCl $\mathrm{Cl}_{4}$ mixtures with density $1.21,1.24,1.27,1.33$, 1.40 and $1.50 \mathrm{~g} / \mathrm{cm}^{3}$ and centrifugation at $3000 \mathrm{rpm}$, rotation radius $25 \mathrm{~cm}$ [35].

For determination of the maceral group in which the $\mathrm{Al}$ complexes are concentrated, seven fractions from the Dukla coal were separated in the same way. The fractions obtained were further leached, while $60-70 \mathrm{~g}$ of sample were mixed with 140 - $150 \mathrm{~mL}$ 2-methoxyethanol and left in capped flasks at room temperature for 20 months, with shaking from time to time. Subsequently, the solid phase from leaching and the solid residue after leaching were analyzed using ${ }^{27} \mathrm{Al}$ MAS NMR spectroscopy. Further, the CSA lignite was leached and separates analyzed in the same way; for comparison, this lignite was leached also with $\mathrm{CCl}_{4}$.

Coal samples/fractions were analyzed without demineralization, i.e. in their original state. The reason is that demineralization [36], unlike sink-float or leaching, may not be friendly to some structures of coal and examined $\mathrm{Al}$ complexes could be damaged.

\subsubsection{Al Minerals}

Minerals for the sensitivity and resolution testing of the NMR method chosen were as follows: $\alpha-\mathrm{Al}_{2} \mathrm{O}_{3}$ (corundum, Korund Benátky, SRO, Czech Rep.); $\gamma$ - $\mathrm{Al}(\mathrm{OH})_{3}$, (gibbsite, Lachema Brno Comp., Czech Rep.); and kaolinite (Kaolin Sedlec IA Standard, Sedlecký Kaolin AS, Czech Rep.).

\subsubsection{Al Complexes}

The reference $\mathrm{Al}$ complexes for assignment of $\mathrm{Al}$ complexes in coal were as follows. Al phenoxide (Sigma $\mathrm{Al}-$ drich); Al-catechin complex, prepared according to Chen et al. [27]; triaquo-triphenoxido-Aluminum(III) complex $\left(\mathrm{Al}\left(\mathrm{H}_{2} \mathrm{O}\right)_{3}\left(\mathrm{C}_{6} \mathrm{H}_{5} \mathrm{O}\right)_{3}\right)$, prepared by EtOH extraction from Al phenoxide phtalocyanine chloride dye (Sigma Aldrich), yield ca. $10 \mathrm{wt} \%$ (based on the work [24]).

Further was used triaquo-hydroxo-diphenoxido-Aluminum(III) complex $\left(\mathrm{Al}\left(\mathrm{H}_{2} \mathrm{O}\right)_{3}(\mathrm{OH})\left(\mathrm{C}_{6} \mathrm{H}_{5} \mathrm{O}\right)_{2}\right)$, prepared by long term reaction of gibbsite powder with phenol (1:1) in water as follows: gibbsite (25 g) was blended with the same amount of phenol and $110 \mathrm{~mL}$ water then added; the suspension was kept in capped flasks at room temperature for 15 months; then conc. $\mathrm{NaOH}$ was added for removal of unreacted phenol. The resulting precipitate was washed and air-dried, subsequently, $500 \mathrm{~mL}$ EtOH was added for leaching; after the EtOH evaporation, the solid phase was the resulting complex in the yield about $10 \mathrm{wt} \%$ [15]. Finally, triaquo-trihydroxo-Aluminum(III) complex $\left(\mathrm{Al}\left(\mathrm{H}_{2} \mathrm{O}\right)_{3}(\mathrm{OH})_{3}\right)$, prepared by long term hydrolysis (20 months) of $\mathrm{AlCl}_{3}$ in water at $\mathrm{pH} 5.5$ [6], (yield ca. $20 \mathrm{wt} \%$ ) was used. 


\subsection{Methods}

\subsubsection{Instrumental Techniques}

Solid state ${ }^{27} \mathrm{Al}$ MAS NMR spectra were recorded using a Bruker Avance $500 \mathrm{WB} / \mathrm{US}$ NMR spectrometer (Karlsruhe, Germany) with $4 \mathrm{~mm}$ double resonance probe heads at MAS rate $\omega_{r} / 2 \pi=12 \mathrm{kHz}$. The spectra were acquired at $130.287 \mathrm{MHz}$, using a tip angle of 20 degrees ( $1 \mu$ s pulse length) with a recycle delay of 2 s. The spectra were referenced to $\mathrm{Al}\left(\mathrm{NO}_{3}\right)_{3}$ at $0.0 \mathrm{ppm}$.

Organic elemental analysis was performed using a Flash 1112 EA analyzer (Thermo Finnigan, Rodano). Analysis of aluminum was carried out with an X-ray fluorescence (XRF) spectrometer (EDS Spectro X-Lab; Spectro Analytical Instruments, Kleve). The coal samples always had ca. 1 wt\% Al.

The maceral composition of the vitrinite, liptinite and inertinite group was assayed using an Opton-Zeiss UMSP 30 Petro microscope (reflected monochromatic light, wavelength $546 \mathrm{~nm}$, immersion objective, magnification $40 \times$, oil immersion with refractive index $n=1.518$ ) and Eltinor point counter for precise determination of the petrographic components according to ISO 7404; also in accord with Taylor et al. [37], ICCP 1998 [38], ICCP 2001 [39] and Scott [40].

For minerals distribution in the high-ash high-density fractions, X-ray analysis was carried out using a Bruker D8 Discover diffractometer using CuK $\alpha$ radiation, at voltage $40 \mathrm{kV}$ and current $40 \mathrm{~mA}$, with a detector LynxEye, in the range of 3 - 69 2Theta. Minerals were evaluated using the databasis Mineral Powder Diffraction DataData Book (1980).

Thermal stability of the prepared complexes was tested by thermogravimetric method using a SETARAM Setsys Evolution 18 analyzer. About 23 - $25 \mathrm{mg}$ of the dry sample was heated at a rate of $10^{\circ} \mathrm{C} / \mathrm{min}$ in an inert atmosphere (He, $20 \mathrm{~cm}^{3} / \mathrm{min}$ ) in the temperature range of $25^{\circ} \mathrm{C}-900^{\circ} \mathrm{C}$.

\subsubsection{MAS NMR Assignment of Al Complexes}

Due to low concentration of $\mathrm{Al}$ complexes in coal, their isolation is very difficult. For identification, it is therefore more feasible to use a highly sensitive and high resolution solid state ${ }^{27} \mathrm{Al}$ MAS NMR spectrometer, have a comparative scale of complexes as reference compounds, and assign complexes in question on the basis of the same or very similar peak shifts (allowable difference of 1 - 2 ppm [17]).

Generally, signals in the range of -20 to $20 \mathrm{ppm}$ are typical for hexa-coordination of $\mathrm{Al}$ to $\mathrm{O}$ in an octahedral arrangement [41], which can be considered for Al complexes in coal [24]. Hexa-coordinated Al affords NMR features which can be correlated with the octahedral symmetry, the number of $\mathrm{Al}$ sites, and the distribution of Al-O distances. Therefore, if various well defined minerals are tested, completely different values should be measured.

Let us consider corundum, gibbsite and kaolinite. As X-ray data show, in corundum $\left(\alpha-\mathrm{Al}_{2} \mathrm{O}_{3}\right), \mathrm{Al}^{3+}$ ions are surrounded by six nearest $\mathrm{O}$ neighbors at 1.849 and $1.980 \AA$ [42] or at 1.855 and $1.972 \AA$ [43], and the four near nearest $\mathrm{Al}^{3+}$ neighbors at 2.65 and $2.79 \AA$ [44]; regarding strong correlations between structural characteristics and ${ }^{27} \mathrm{Al}$ MAS NMR spectral parameters in Al oxides and hydroxides [19], a significant NMR signal is expected from Al-O bonds. Since a further compound, gibbsite $\left(\gamma-\mathrm{Al}(\mathrm{OH})_{3}\right)$, consists of octahedral layers with two Al sites with the Al-O distances spread over 1.832 to $1.947 \AA$ [45], a different NMR signal from corundum would be expected. The third mineral, kaolinite, has two Al sites like gibbsite, but the Al-O distances are between 1.880 and $1.969 \AA$ [46] without a resolved mode. In kaolinite, a gibbsite-like layer is associated to a tetrahedral Si layer; therefore, a different NMR signal would again be expected. On this basis, both the sensitivity and resolution of the method and spectrometer used for the environment of $\mathrm{Al}^{3+}$ were tested.

First, corundum was tested, in which the $\mathrm{Al}^{3+}$ ions are bonded in distorted octahedra; for this, a peak shift at $14.2 \mathrm{ppm}$ was recorded (Figure 1). The second compound, gibbsite, again with distorted octahedra, exhibited a shift at $8.9 \mathrm{ppm}$. The basic structure of gibbsite is practically identical to that of corundum, except that the oxygens are replaced by $\mathrm{OH}$ groups. Therefore, the gibbsite chemical environment is different from corundum. The ${ }^{27}$ Al MAS NMR signal obtained was sensitive to the local Al environment and the difference between peak shifts was recorded. Finally, kaolinite was tested. In this case, a peak shift at 4.8 ppm was obtained (Figure 2). It is evident that the peak shifts were distinctly different, reflecting the differences between the chemical environment of the $\mathrm{Al}^{3+}$ ions. A similar effect was expected for $\mathrm{Al}$ complexes listed in Table 1.

These complexes were chosen as references, based on long term experience with the analysis of ${ }^{27} \mathrm{Al}$ MAS NMR spectra from coals, their leachates with organic solvents, notably 2-methoxyethanol, and investigation of 


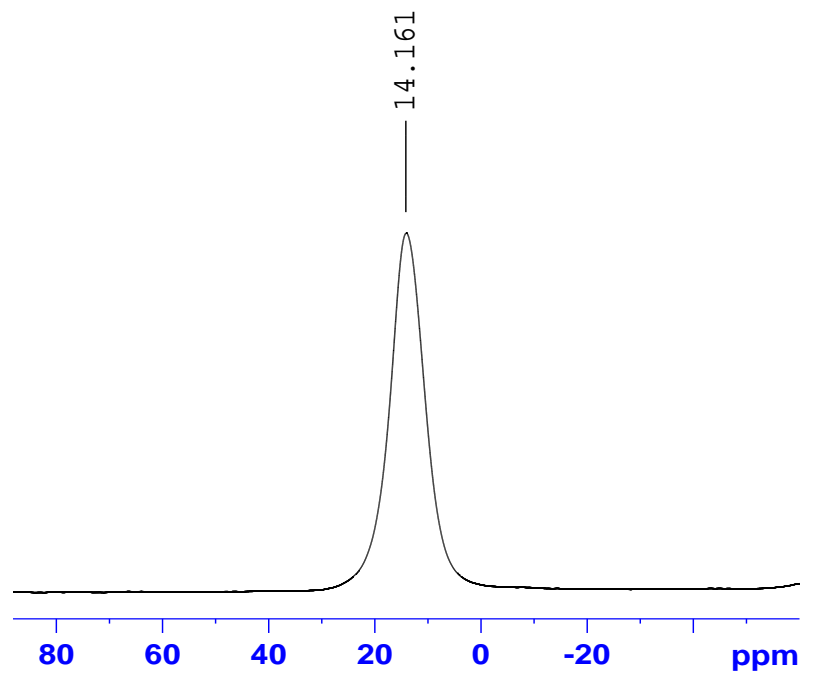

Figure $1 .{ }^{27} \mathrm{Al}$ MAS NMR spectrum of corundum with peak shift at $14.2 \mathrm{ppm}$.

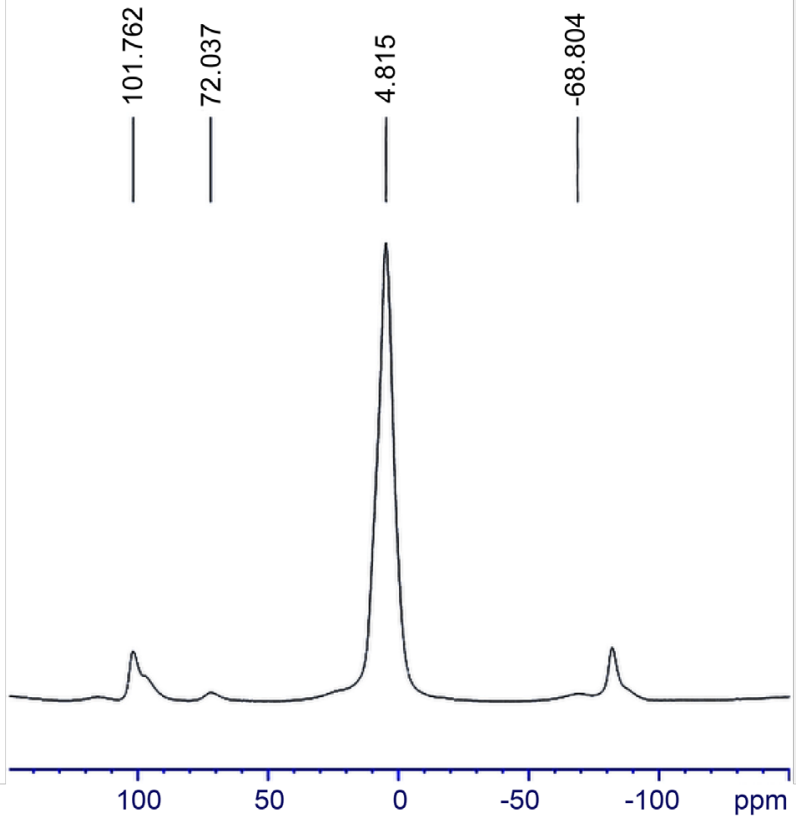

Figure 2. ${ }^{27} \mathrm{Al}$ MAS NMR spectrum of kaolinite with peak shift at $4.8 \mathrm{ppm}$. Peak at $72 \mathrm{ppm}$ is due to tetrahedral site. (A double-resonance 4-mm probe head, spectrum acquired at $130.287 \mathrm{MHz}$, the spinning frequency of $12 \mathrm{kHz}$, tip angle $20^{\circ}$ (1 $\mu$ sulse length), a recycle delay of $2 \mathrm{~s}$, external standard $\mathrm{Al}\left(\mathrm{NO}_{3}\right)_{3}$.

Table 1. Reference complexes for identification of $\mathrm{Al}$ complexes in coal and their peak shifts in ${ }^{27} \mathrm{Al}$ MAS NMR spectra.

\begin{tabular}{|c|c|c|}
\hline Reference complex & Peak shift (ppm) & Description \\
\hline Al phenoxide & 20.9 & $\mathrm{Al}\left(\mathrm{C}_{6} \mathrm{H}_{5} \mathrm{O}\right)_{3}$. \\
\hline Al-catechin complex & 16.2 & Al bonded to polyphenol molecule(s). \\
\hline $\mathrm{Al}\left(\mathrm{H}_{2} \mathrm{O}\right)_{3}\left(\mathrm{C}_{6} \mathrm{H}_{5} \mathrm{O}\right)_{3}$ & & $\mathrm{Al}^{3+}$ hexa-coordinated with oxygen from phenoxide anions and \\
\hline (TTA) & 14.2 & water ligands. \\
\hline $\begin{array}{l}\mathrm{Al}\left(\mathrm{H}_{2} \mathrm{O}\right)_{3}(\mathrm{OH})\left(\mathrm{C}_{6} \mathrm{H}_{5} \mathrm{O}\right)_{2} \\
\text { (THDA) }\end{array}$ & 3.8 & $\begin{array}{l}\mathrm{Al}^{3+} \text { hexa-coordinated to the phenoxide, } \\
\text { hydroxo and water oxygens. }\end{array}$ \\
\hline $\mathrm{Al}(\mathrm{OH})_{3}\left(\mathrm{H}_{2} \mathrm{O}\right)_{3}$ & -1.4 & $\begin{array}{l}\mathrm{Al} \text { complex with symmetrically arranged } \mathrm{OH} \text { and water ligands. } \\
\text { (Basic complex found in xylite.) }\end{array}$ \\
\hline
\end{tabular}


Al complexes with organic ligands. The first reference compound in Table $1, \mathrm{Al}$ phenoxide, showed a signal at $20.9 \mathrm{ppm}$ [24] with a broad asymmetric peak in a range of ca. -20 to $30 \mathrm{ppm}$. Thus, irregularly arranged phenoxide ions exist in the chemical environment of $\mathrm{Al}^{3+}$. On the contrary, the $\mathrm{Al}(\mathrm{OH})_{3}\left(\mathrm{H}_{2} \mathrm{O}\right)_{3}$ complex exhibited a symmetrical peak at $-1.4 \mathrm{ppm}$, so, this complex has symmetrically arranged ligands and a quite different peak shift as compared with Al phenoxide (Figure 3).

However, if two $\mathrm{OH}$ groups are replaced by phenoxide anions in the $\mathrm{Al}\left(\mathrm{H}_{2} \mathrm{O}\right)_{3}(\mathrm{OH})\left(\mathrm{C}_{6} \mathrm{H}_{5} \mathrm{O}\right)_{2}$ (triaquo-hydroxo-diphenoxido-Aluminum(III), THDA, Figure 4), the chemical shift was $3.8 \mathrm{ppm}$, with an asymmetric peak (Figure 5). Further, when $3 \mathrm{C}_{6} \mathrm{H}_{5} \mathrm{O}^{-}$ions or a polyphenol molecule/polyphenol molecules are present as ligands, the triaquo-triphenoxido-Aluminum(III) complex $\left(\mathrm{Al}\left(\mathrm{H}_{2} \mathrm{O}\right)_{3}\left(\mathrm{C}_{6} \mathrm{H}_{5} \mathrm{O}\right)_{3}\right.$, TTA, Figure 6) or Al-catechin complex are formed. In this case, the peak shift values were quite different, specifically at 14.2 or $16.2 \mathrm{ppm}$, respectively (Table 1). On the whole, in the range of -20 to $20 \mathrm{ppm}$, peak shifts reflected the chemical environment differences between the standards as expected.

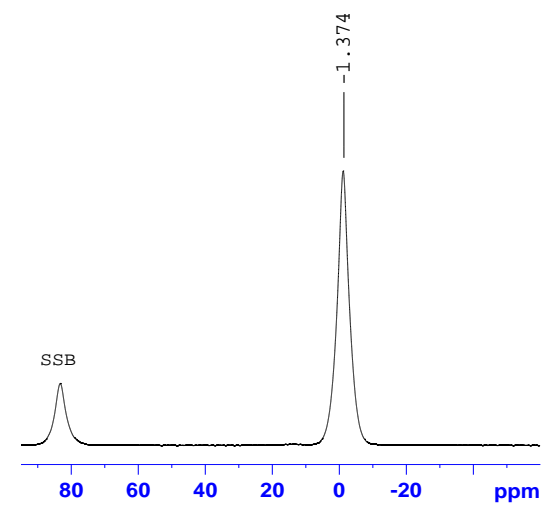

Figure 3. ${ }^{27} \mathrm{Al}$ MAS NMR spectrum of $\mathrm{Al}(\mathrm{OH})_{3}\left(\mathrm{H}_{2} \mathrm{O}\right)_{3}$ complex with a symmetrical peak at $-1.4 \mathrm{ppm}$.<smiles>OC(O)(O)Oc1ccccc1</smiles>

Figure 4. Triaquo-hydroxo-diphenoxido-Aluminum(III) complex (THDA).

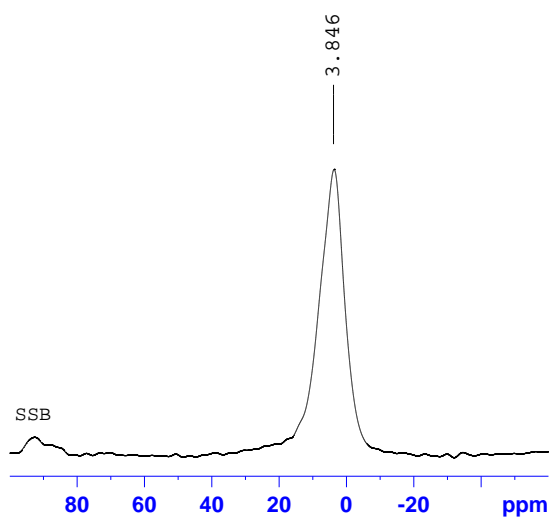

Figure 5. ${ }^{27} \mathrm{Al}$ MAS NMR spectrum of $\mathrm{Al}\left(\mathrm{H}_{2} \mathrm{O}\right)_{3}(\mathrm{OH})\left(\mathrm{C}_{6} \mathrm{H}_{5} \mathrm{O}\right)_{2}$ complex (THDA) with asymmetric peak at 3.8 ppm. (SSBspinning sideband.) 


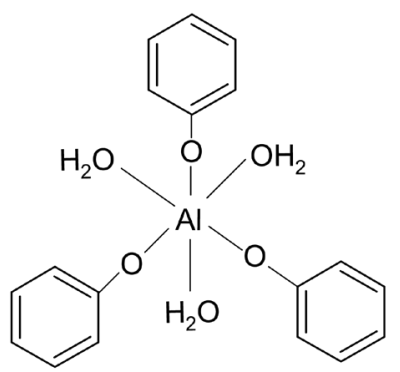

Figure 6. Triaquo-triphenoxido-Aluminum(III) complex (TTA).

Practically the same peak shifts of those registered for the reference Al complexes were also found in spectra of the low ash coal samples (Figure 7 and Figure 8, see below). The significant peak at chemical shift of the $\mathrm{Al}(\mathrm{OH})_{3}\left(\mathrm{H}_{2} \mathrm{O}\right)_{3}$ complex was the same as that for xylite (see below).

\section{Results and Discussion}

\subsection{Identification of Al Complexes in Coal}

The coal samples always had about $1 \mathrm{wt} \%$ Al (air-dry basis). Although only low ash samples were examined (Table 2), mineralogical analysis was carried out and distribution of minerals determined. The reason is that $\mathrm{Al}$ minerals could disturb the identification of Al complexes. Distribution of minerals was evaluated with the high-ash high-density fractions $\left(>1.5 \mathrm{~g} / \mathrm{cm}^{3}\right)$, separated from Czech coals and lignite, Australian and Chinese coals and thermally altered coals (Table 2). From Table 2 it follows that in 6 cases prevails dolomite (high density fractions from 5 Czech bituminous coals and the altered coal Lazy; the results obtained are in agreement with Dopita [47]; in 2 cases calcite (Chinese coal and the altered coal Kladno), and in the other 2 cases quartz (Australian coal and ČSA lignite).

In the case of Czech anthracite (ash content $2.98 \mathrm{wt} \%$ ), gagatite (ash content $1.51 \mathrm{wt} \%$ ) and xylite (ash content $2.49 \mathrm{wt} \%$ ), the content of minerals was below the XRD detection limit, therefore, the qualitative mineralogical composition was taken from the literature [48] [49]. As it is clear from these works, calcite/dolomite, quartz, pyrite, and a small amount of clay minerals are present. In Russian and Ukrainian anthracites (ash content 2.66 and $3.46 \mathrm{wt} \%$, respectively), the mineral contents were below the XRD detection limit, too, however, regarding the works [50] [51] the occurrence of quartz, pyrite dolomite and kaolinite can be assumed. In summary, the samples listed in Table 2 were suitable for identification of Al complexes, because they had low ash content and in their mineral composition dominated mostly carbonates and quartz, not Al-minerals.

Because only low ash samples with prevailing non-Al minerals in a very minor mineral part of coal were measured, the results were related to $\mathrm{Al}$ complexes in coal organic matter. Generally, due to above-mentioned affinity of $\mathrm{Al}$ for coal organic matter and a strong ability to form complexes, the occurrence of $\mathrm{Al}$ complexes with organic ligands in the coal samples is highly likely. The signals obtained from anthracite, bituminous coal, lignite, gagatite, altered coal and xylite are shown in Table 3. Different types of spectra were registered, with signals in the range of ca. -20 to $20 \mathrm{ppm}$. With anthracite, the peak shift was at $15 \mathrm{ppm}$, with bituminous coal the peak shifts at 3.4 - 4 and 13.5 - 14 ppm were recorded. In the case of lignite and gagatite, a peak shift at 3.5 $4 \mathrm{ppm}$ was obvious, while the ČSA lignite from the Northern Bohemian Basin showed beside peak at 3.5 the peak shift at $13.6 \mathrm{ppm}$. Contrasting results were obtained for thermally altered samples. While the weakly altered Kladno coal (Central Bohemian Basin) showed a single peak at $4.2 \mathrm{ppm}$, the more altered Lazy coal (Upper Silesian Basin) showed three peaks, at 5.2, 15.9 and 71.9 ppm. Finally, with xylite the peak shift was at 0.8 ppm. All these peak shifts were compared with those from the reference Al complexes (Table 1).

As mentioned above, with some bituminous coals, lignite and gagatite, a peak shift at 3.5 - 4 ppm was observed. A typical spectrum is shown in Figure 7 (An Tai Bao coal, China, Shanxi Province, ash content 2.74 $w t \%)$. The peak shift (at $3.6 \mathrm{ppm}$ ) is very close to that of the THDA complex (Table 1), therefore, THDA or a THDA-like complex could be suggested as a component of the coal.

Peak shifts in the following Figures 8-10 were assessed with regard to works [18] [19] [52]. In the case of the Dukla, Darkov, Paskov, Peak Downs and ČSA samples, along with a signal 3.5 - 4 ppm, the peak at 13.5 - 14 ppm was registered (Figure 8 and Figure 9). Consequently, another quite different Al complex in these coals 
Table 2. Ash content of selected coals, lignites and altered coals and distribution of minerals determined with the high-ash high-density fractions $\left(>1.5 \mathrm{~g} / \mathrm{cm}^{3}\right)$ by XRD. (CZ-Czech Republic.)

\begin{tabular}{|c|c|c|c|}
\hline Coal type & Locality/state & Ash (wt\%) & Distribution of minerals in $+1.5 \mathrm{~g} / \mathrm{cm}^{3}$ fraction (\%) \\
\hline \multirow[t]{3}{*}{ Anthracites: } & Czech Rep. & 2.98 & - \\
\hline & Russia & 2.66 & - \\
\hline & Ukraine & 3.46 & - \\
\hline \multirow[t]{7}{*}{ Bituminous: } & $\begin{array}{l}\text { Dukla/CZ, fraction } 1.27-1.33 \\
\mathrm{~g} / \mathrm{cm}^{3}\end{array}$ & 2.39 & $\begin{array}{l}\text { Dolomite (33.1), kaolinite (26.8), goethite (17.3), } \\
\text { muscovite (13.3), quartz (9.5) }\end{array}$ \\
\hline & $\begin{array}{l}\text { 9.květen } / \mathrm{CZ} \text {, fraction } \\
1.24-1.29 \mathrm{~g} / \mathrm{cm}^{3}\end{array}$ & 1.05 & $\begin{array}{l}\text { Dolomite (47.2), calcite (21.4), kaolinite (11.8), quartz (8.9), } \\
\text { pyrite (7.4), siderite (3.3) }\end{array}$ \\
\hline & Darkov/Czech Rep. & 2.58 & $\begin{array}{c}\text { Dolomite (48.9), calcite (25.6), kaolinite (15.2), pyrite (6.2), } \\
\text { siderite (4.1) }\end{array}$ \\
\hline & Paskov/Czech Rep. & 1.49 & Dolomite (59.6), calcite (28.9), pyrite (8.3), kaolinite (3.2) \\
\hline & $\begin{array}{l}\text { Staříč } / \mathrm{CZ} \text {, fraction } \\
\quad<1.30 \mathrm{~g} / \mathrm{cm}^{3}\end{array}$ & 1.80 & $\begin{array}{c}\text { Ferroan dolomite (55.5), calcite (26.6), siderite (7.7), pyrite } \\
\text { (7.5), kaolinite (2.7) }\end{array}$ \\
\hline & Peak Downs/Australia & 4.43 & Quartz (81.0), kaolinite (19.0) \\
\hline & An Tai Bao/China & 2.74 & Calcite (65.2), pyrite (18.5), kaolinite (16.3) \\
\hline Lignite: & ČSA/Czech Rep. & 4.10 & $\begin{array}{l}\text { Quartz (39.2), gypsum (24.5), goethite (14.8), kaolinite (14.6), } \\
\text { muscovite (6.9) }\end{array}$ \\
\hline Gagatite: & Poland & 1.51 & - \\
\hline \multirow[t]{2}{*}{ Altered: } & Kladno/Czech Rep. & 4.40 & Calcite (91.0), kaolinite (9.0) \\
\hline & Lazy/Czech Rep. & 2.70 & $\begin{array}{c}\text { Dolomite (31.3), siderite (29.1), gypsum (17.6), pyrite (13.2), } \\
\text { calcite (4.7), quartz (4.1) }\end{array}$ \\
\hline Xylite: & Nová Ves/Czech Rep. & 2.49 & - \\
\hline
\end{tabular}
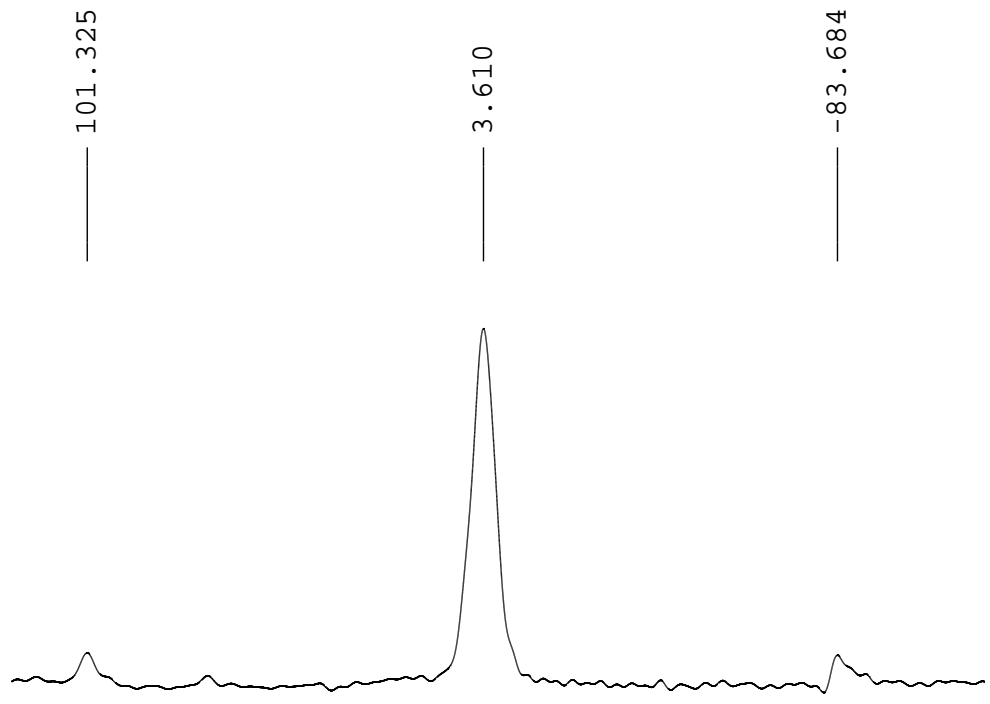

\begin{tabular}{r|rrrr}
1 & 1 & 1 & 1 & 1 \\
100 & 50 & 0 & -50 & $\mathrm{ppm}$
\end{tabular}

Figure $7 .{ }^{27} \mathrm{Al}$ MAS NMR spectrum of An Tai Bao coal (China, Shanxi province). 


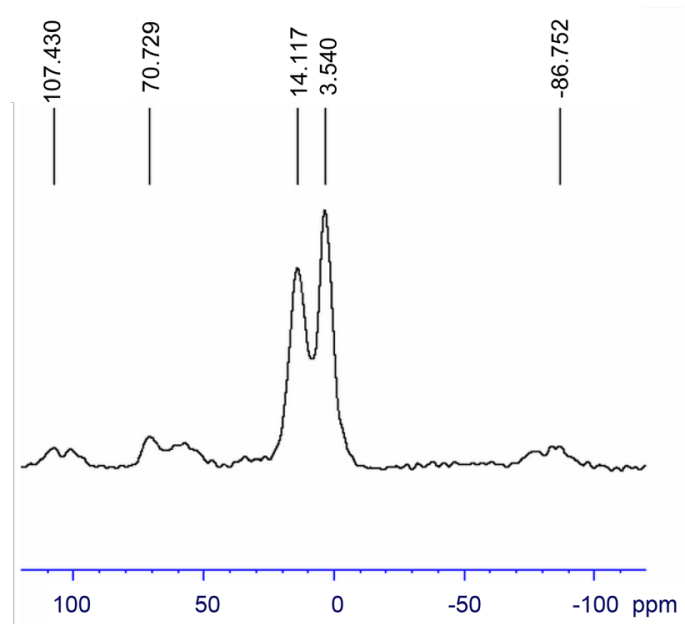

Figure 8. ${ }^{27} \mathrm{Al}$ MAS NMR spectrum of peak downs coal (Australia, Qeensland). In a mineral part of coal (4 wt\%) completely dominated quartz (Table 2).

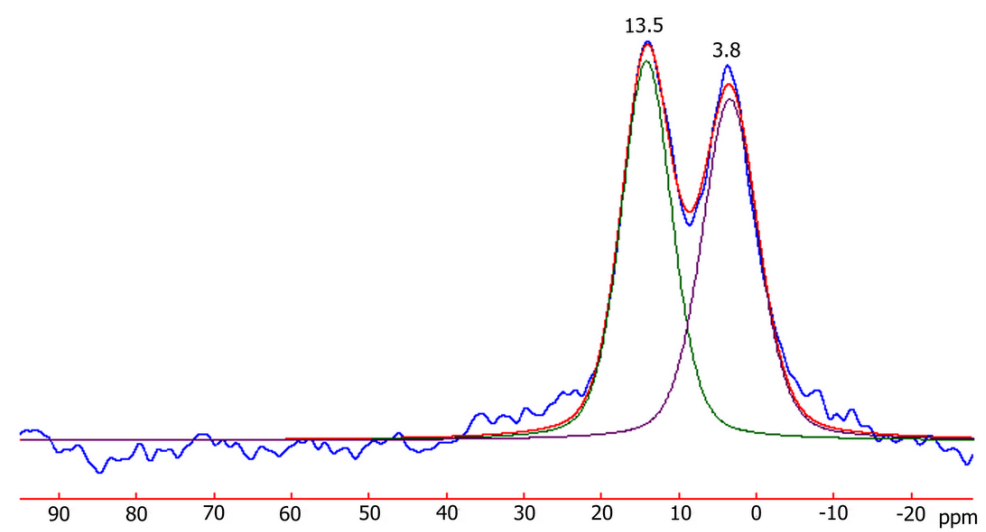

Figure 9. ${ }^{27} \mathrm{Al}$ MAS NMR spectrum of Paskov coal (Upper Silesian Basin, Czech Rep.) with two different peak shifts corresponding to two Al complexes.

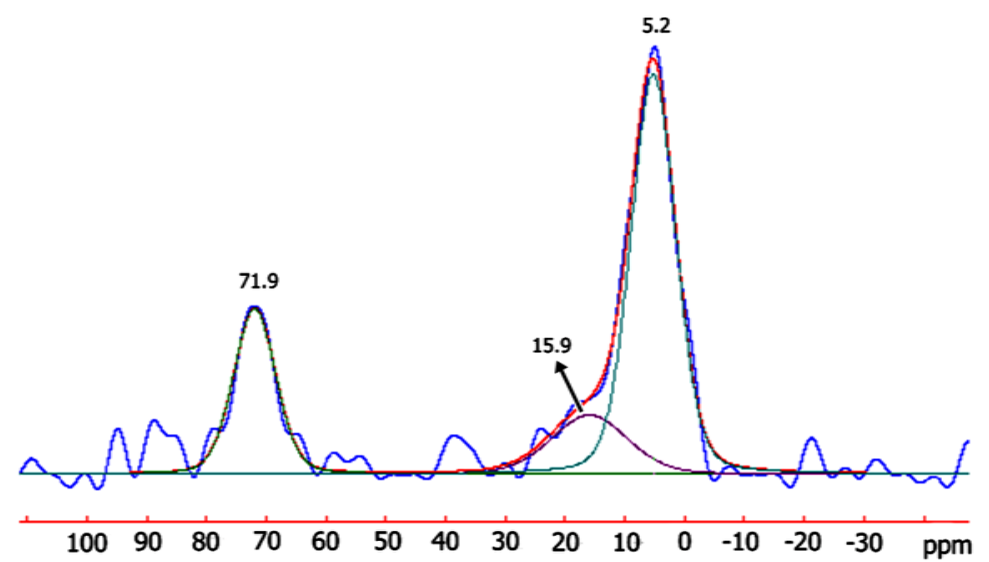

Figure 10. ${ }^{27} \mathrm{Al}$ MAS NMR spectrum of thermally altered Lazy coal (Upper Silesian Basin, Czech Rep.). No Al minerals were present in coal (Table 2). The peak shift at $71.9 \mathrm{ppm}$ corresponds therefore to certain organic structure with $\mathrm{Al}$ tetra-coordinated to $\mathrm{O}$. 
must be considered besides a THDA/THDA-like complex. From Table 1 it follows that TTA or TTA-like complexes could be suggested in this case. Correspondingly, anthracite samples gave the peak shifts at 15.2, 15.3, and $15.4 \mathrm{ppm}$ (Table 3), like the TTA complex; it is reasonable to ascribe these values to a TTA or TTA-like complex, however, an Al-catechin or Al-catechin-like complex with a chemical shift at 16 ppm (Table 1) could also be considered.

Furthermore, in the case of the thermally altered coal Lazy (Upper Silesian Basin, ash content $2.70 \mathrm{wt} \%$ ), also the peak at $15.9 \mathrm{ppm}$ (peak area $15.3 \%$ of the total area of peaks) along with a signal at $5.2 \mathrm{ppm}$ (peak area $61.0 \%$ of the total peaks area) was registered; but, moreover, the symmetrical peak at $71.9 \mathrm{ppm}$ (peak area $23.7 \%$ of the total peaks area) was observed (Figure 10). As Al tetra-coordinated with $\mathrm{O}$ shows a typical shift at $60-80 \mathrm{ppm}$ [53] it could be deduced that, during long-term thermal alteration, THDA and/or TTA complexes with Al hexacoordinated to $\mathrm{O}$ were partly transformed to organic structure/structures with Al tetra-coordinated to O [54]. It must be emphasized that Lazy coal contained only $2.70 \mathrm{wt} \%$ of ash, moreover, a mineral admixture did not contain kaolinite or other $\mathrm{Al}$ minerals (Table 2). Therefore, the thermal alteration took place in the organic matter of coal.

In this connection, thermal processing conditions of this transformation were considered. According to altered coals classification [55], the Lazy coal used is the zero oxidative and higher thermally altered subtype, formed in the vicinity of a red beds body. The thermal alteration of this coal was investigated by Kurková [56]. Based on laboratory experiments with heating of a non-altered Lazy coal at different times (1-n.100 h) and the model calculations, it was shown that 1 ) during alteration, the coal was thermally processed at $100^{\circ} \mathrm{C}-200^{\circ} \mathrm{C}$ for a long time, 2) for the determination of maximum temperature of alteration is applicable a statistical linear relationship (Equation 1) according to Barker and Pawlewitz [57], further reported and commented in the work [58]. In Equation (1), $R_{r}$ is the mean vitrinite reflectance (\%) and $t_{\max }$ the maximum temperature $\left({ }^{\circ} \mathrm{C}\right)$.

$$
\ln \left(R_{r}\right)=0.0078 t_{\max }-1.2
$$

As $R_{r}$ was $0.97 \% \pm 0.05 \%$ with altered Lazy coal (according to ISO 7404 ), the maximum temperature of coal alteration can be estimated approximately $150^{\circ} \mathrm{C}$. It can be deduced that transformation of complexes with $\mathrm{Al}$ hexa-coordinated to $\mathrm{O}$ to certain organic structure with $\mathrm{Al}$ tetra-coordinated to $\mathrm{O}$ occurred at temperatures below $150^{\circ} \mathrm{C}$.

In addition, the occurrence of $\mathrm{Al}$ complexes in xylite was investigated. With xylite from the Cheb Basin (Tertiary brown coal basin, Czech Rep.) the peak shift at $0.8 \mathrm{ppm}$ was obvious (Figure 11). Since this value corresponds to that for the $\mathrm{Al}(\mathrm{OH})_{3}\left(\mathrm{H}_{2} \mathrm{O}\right)_{3}$ complex $(-1.4 \mathrm{ppm}$, Figure 3), it is evident that the Al complex in xylite differed significantly from those in anthracite, bituminous coal, and lignite.

As stated above, for solving some geochemical issues and outstanding questions of temperature conditions of coal formation, the thermal stability of $\mathrm{Al}$ complexes identified in coal is important. Therefore, this question was solved together with identification and characterization of complexes in question in following section.

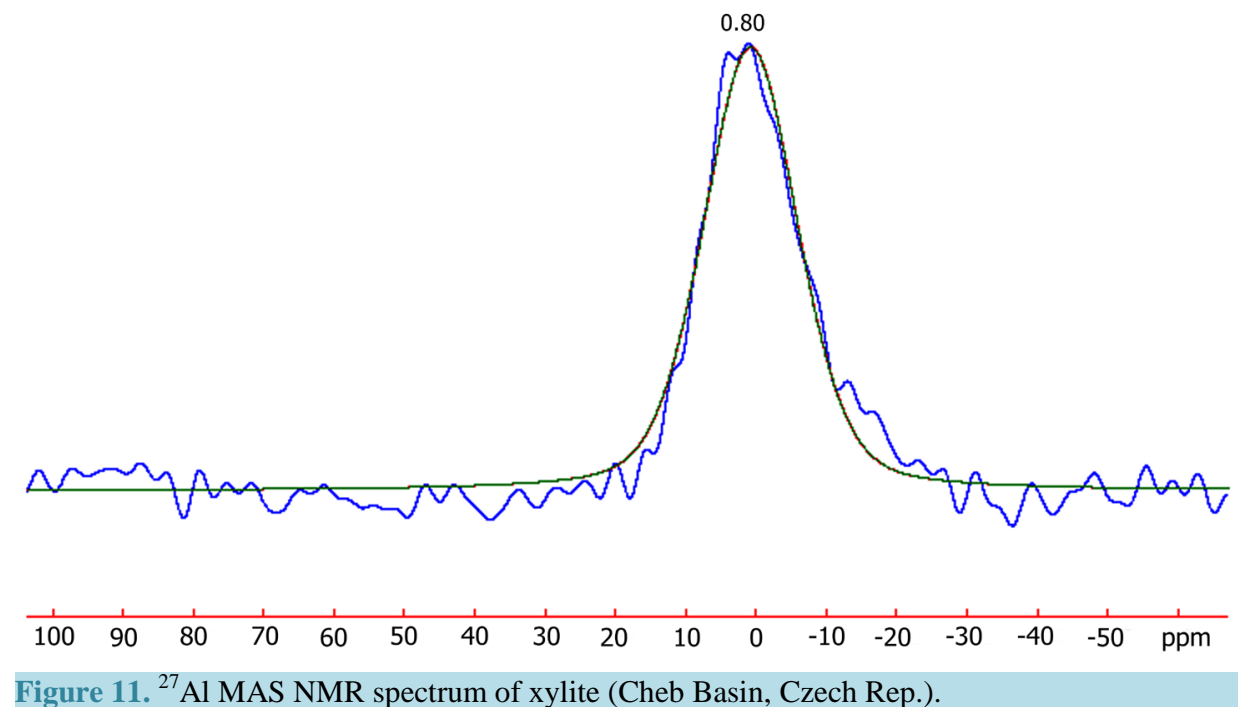


Table 3. ${ }^{27} \mathrm{Al}$ MAS NMR signals for coals, coal fractions, gagatite and xylite (CZ-Czech Rep.). In the case of Dukla, 9. květen and Staříč coals, the density fractions (see Table 2) were measured. Range of signal/signals (ppm) corresponds to the total width of the resonance lines.

\begin{tabular}{|c|c|c|c|}
\hline Coal/mine & Basin/locality/state & $\begin{array}{l}\text { Peak shift } \\
\text { (ppm) }\end{array}$ & Range of signal/signals (ppm) \\
\hline \multirow{3}{*}{$\begin{array}{l}\text { Anthracites: } \\
\text { Bituminous: }\end{array}$} & Czech Republic & 15.3 & $0-20$ \\
\hline & Russia & 15.4 & $0-20$ \\
\hline & Ukraine & 15.2 & $0-20$ \\
\hline $\begin{array}{l}\text { Dukla } \\
\text { 9. květen }\end{array}$ & & $\begin{array}{c}3.6 ; 14.5 \\
4.0\end{array}$ & $\begin{array}{c}-5-10 ; 5-20 \\
-5-15\end{array}$ \\
\hline $\begin{array}{l}\text { Darkov } \\
\text { Paskov } \\
\text { Staříč }\end{array}$ & Upper Silesian Basin/CZ & $\begin{array}{c}3.4 ; 14.1 \\
3.8 ; 13.5 \\
13.8\end{array}$ & $\begin{array}{l}-5-15 ; 5-20 \\
-10-10 ; 0-20 \\
-10-20\end{array}$ \\
\hline Peak Downs & Qeensland, Australia & $3.5 ; 14.1$ & $-10-0 ;-10-20$ \\
\hline An Tai Bao & Shanxi, China & 3.6 & $-5-12$ \\
\hline \multicolumn{4}{|l|}{ Lignite: } \\
\hline ČSA & Northern Bohemian Basin/CZ & $3.5 ; 13.6$ & $-5-10 ; 5-20$ \\
\hline Gagatite: & Poland & $\sim 3.5$ & $-5-10$ \\
\hline \multicolumn{4}{|l|}{ Altered: } \\
\hline $\begin{array}{l}\text { Kladno } \\
\text { Lazy } \\
\text { Xylite: } \\
\text { Nová Ves }\end{array}$ & $\begin{array}{c}\text { Central Bohemian Basin/CZ } \\
\text { Upper Silesian Basin/CZ } \\
\text { Cheb Basin/CZ }\end{array}$ & $\begin{array}{c}4.2 \\
5.2 ; 15.9 ; 71.9 \\
0.8\end{array}$ & $\begin{array}{c}-10-20 \\
-5-15 ; 0-20 ; 65-80 \\
-20-20\end{array}$ \\
\hline
\end{tabular}

\subsection{Thermal Stability of Al Complexes Identified in Coal}

The thermal stability of $\mathrm{Al}(\mathrm{OH})_{3}\left(\mathrm{H}_{2} \mathrm{O}\right)_{3}$, THDA and TTA complexes was investigated thermogravimetrically, by TG/DTG method. It was found that the thermal decomposition of $\mathrm{Al}(\mathrm{OH})_{3}\left(\mathrm{H}_{2} \mathrm{O}\right)_{3}$ starts at $75^{\circ} \mathrm{C}$ and its decomposition proceeds with elimination of water molecules up to ca. $120^{\circ} \mathrm{C}$ while $\mathrm{Al}(\mathrm{OH})_{3}$ is formed. $\mathrm{Al}(\mathrm{OH})_{3}$ then decomposes up to about $225^{\circ} \mathrm{C}$ to form $\gamma$ - $\mathrm{AlO}(\mathrm{OH})$ (by reaction $\mathrm{Al}(\mathrm{OH})_{3}=\gamma-\mathrm{AlO}(\mathrm{OH})+\mathrm{H}_{2} \mathrm{O}$ ), due to the fact that the thermal stability of $\gamma-\mathrm{AlO}(\mathrm{OH})$ is higher than that of $\mathrm{Al}(\mathrm{OH})_{3}$ [59]. Subsequently proceeds the conversion of $\gamma$ - $\mathrm{AlO}(\mathrm{OH})$ to $\gamma-\mathrm{Al}_{2} \mathrm{O}_{3}$ (by reaction $2 \gamma-\mathrm{AlO}(\mathrm{OH})=\gamma-\mathrm{Al}_{2} \mathrm{O}_{3}+\mathrm{H}_{2} \mathrm{O}$ ) up to $350^{\circ} \mathrm{C}$, with maximum of decomposition at ca. $300^{\circ} \mathrm{C}$, in accordance with [59]. Therefore, $\mathrm{Al}(\mathrm{OH})_{3}\left(\mathrm{H}_{2} \mathrm{O}\right)_{3}$ complex can be considered as stable up to ca. $75^{\circ} \mathrm{C}$. Thermal stability of THDA complex is obvious from Figure 12. The beginning of decomposition was registered at $97^{\circ} \mathrm{C}$, the maximum decomposition at $143^{\circ} \mathrm{C}$ and complete decomposition after reaching of temperature approximately $160^{\circ} \mathrm{C}$. A similar progression was observed in the decomposition of TTA. Thus, THDA and TTA complexes can be considered as stable up to ca. $95^{\circ} \mathrm{C}$. On the whole, the thermal stability of studied $\mathrm{Al}$ complexes is not too high.

\subsection{Separation of THDA and TTA Complexes}

Previous data show that at least two Al complexes could be considered for bituminous coal and lignite. The question is whether or not they could be separated from one another. In this respect, some Al complexes are soluble in polar solvents [5], which are favorable for their extraction from coal. The Dukla coal and ČSA lignite were therefore leached with 2-methoxyethanol; the solid phase from the leachate and the solid residue after leaching were analyzed using ${ }^{27} \mathrm{Al}$ MAS NMR. The results are summarized in Table 4.

It can be seen from Table 4 that both Al complexes can be successfully separated using 2-methoxyethanol. The spectra from the solid phase of the leachates showed a peak shift at $15 \mathrm{ppm}$ (corresponding to TTA soluble in 2-methoxyethanol; no Al minerals can be present in the leachate) and those from the solid residue after leaching at 3 - 4 ppm (corresponding to THDA insoluble in 2-methoxyethanol). 


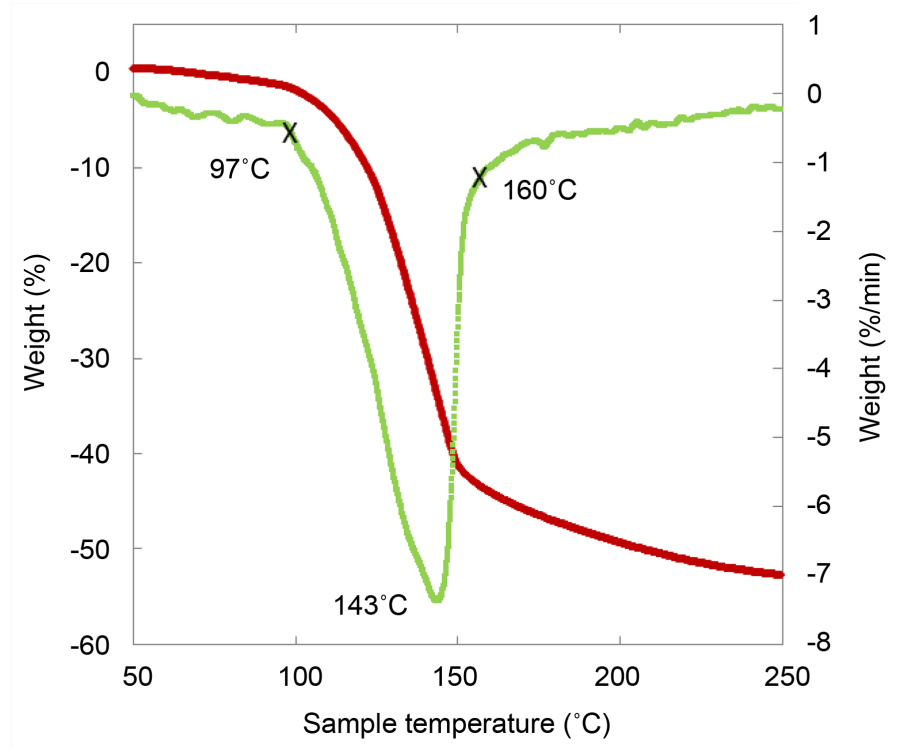

Figure 12. ${ }^{27} \mathrm{Al}$ MAS NMR spectrum of xylite (Cheb Basin, Czech Rep.).

Table 4. ${ }^{27} \mathrm{Al}$ MAS NMR analysis of solid phase of leachates and solid residues after leaching of the Duklabituminous coal and ČSA lignite (2-MOE-2-methoxyethanol).

\begin{tabular}{cccc}
\hline Coal/lignite & 2-MOE separate & Peak shift (ppm) & Assignment \\
\hline \multirow{2}{*}{ Dukla } & Solid phase of leachate & 14.5 & TTA \\
& Solid residue after leaching & 3.6 & THDA \\
\multirow{2}{*}{ ČSA } & Solid phase of leachate & 14.6 & TTA \\
& Solid residue after leaching & 3.4 & THDA \\
\hline
\end{tabular}

These findings prove that at least one, but probably two Al complexes with different properties were present in the coal organic matter of the samples; moreover, it is evident that petrographically characterized coal fractions can also be leached and further analyzed with the ${ }^{27} \mathrm{Al}$ MAS NMR method. In this way, the coal maceral group in which the $\mathrm{Al}$ complexes are concentrated could be determined. Fractions from the Dukla coal were therefore prepared using the sink-float method with xylene- $\mathrm{CCl}_{4}$ mixtures, analyzed (Table 5) and petrographically characterized (Table 6). As a TTA complex is soluble in 2-methoxyethanol, the fractions were further leached with it and the resulting separates analyzed. The results are shown in Table 6.

Table 6 shows that neither the leachate solid phase nor the solid residue after leaching of the low density fractions (<1.21, $1.21-1.24$, and $1.24-1.27 \mathrm{~g} / \mathrm{cm}^{3}$ ) with the lowest ash content exhibited no NMR signals. It means that no Al complexes were in these fractions. On the contrary, the fraction with medium density 1.27 $1.33 \mathrm{~g} / \mathrm{cm}^{3}$ exhibited the strong signals at 3.6 and $14.5 \mathrm{ppm}$, while the solid phase from leachate showed a signal at $14.5 \mathrm{ppm}$ (corresponding to TTA) and solid residue after leaching at $3.6 \mathrm{ppm}$ (corresponding to THDA). Both signals were attributed to Al complexes, because the ash content in this fraction was only $2.39 \mathrm{wt} \%$ and practically no $\mathrm{Al}$ minerals were present. (Al minerals were present only in the highest-density high-ash fraction, Table 2). With higher density fractions (1.33 - 1.40 and $\left.1.40-1.50 \mathrm{~g} / \mathrm{cm}^{3}\right)$ no signals were registered. But with the highest density high-ash fraction (>1.50 g/ $\mathrm{cm}^{3}$, high-ash fraction with $50.22 \mathrm{wt} \%$ of ash, dry basis) was observed in a solid residue after leaching rather stronger signal at $3.6 \mathrm{ppm}$ attributed to kaolinite and muscovite (Table 2; [60]). In summary, 1) no Al complexes were found in the low density fractions; 2) Al complexes THDA and TTA were identified in the $1.27-1.33 \mathrm{~g} / \mathrm{cm}^{3}$ fraction; 3) Al minerals were concentrated in the highest density fraction.

Since petrographic composition of the medium density fraction of the Dukla coal exhibited the dominant vitrinite content of 68\% (Table 7), it could be deduced that TTA and THDA complexes were concentrated mainly in vitrinite. Attention was therefore focused on the vitrinite maceral group in the individual fractions and 
Table 5. Elemental analysis of fractions from Dukla coal (wt\%, dry ash free basis).

\begin{tabular}{ccccccc}
\hline Fraction $\left(\mathrm{g} / \mathrm{cm}^{3}\right)$ & $\mathrm{C}$ & $\mathrm{H}$ & $\mathrm{N}$ & $\mathrm{S}_{\mathrm{o}}$ & $\mathrm{O}_{\text {dif }}$ \\
\hline$<1.21$ & 82.48 & 5.46 & 1.41 & 0.64 & 10.01 \\
$(1.21-1.24)$ & 85.28 & 5.43 & 1.46 & 0.47 & 7.36 \\
$(1.24-1.27)$ & 82.04 & 5.53 & 1.31 & 0.65 & 0.65 & 9.47 \\
$(1.27-1.33)$ & 82.81 & 5.03 & 5.01 & 1.53 & 0.69 & 9.99 \\
$(1.33-1.40)$ & 83.03 & 4.89 & 1.09 & 0.69 & 0.95 \\
$(1.40-1.50)$ & 82.84 & 4.18 & 0.99 & 0.78 & 22.22 \\
\hline$>1.50$ & 71.83 & & & & 29 \\
\hline
\end{tabular}

Table 6. ${ }^{27} \mathrm{Al}$ MAS NMR analysis of solid phase of leachates and solid residues after leaching for individual fractions of Dukla coal (2-MOE-2-methoxyethanol). (-): not detected.

\begin{tabular}{|c|c|c|c|c|c|}
\hline $\begin{array}{l}\text { Fraction } \\
\left(\mathrm{g} / \mathrm{cm}^{3}\right)\end{array}$ & Vitrinite & $\begin{array}{l}\text { Liptinite } \\
\text { (vol\%) }\end{array}$ & Inertinite & 2-MOE separate & $\begin{array}{l}\text { Shift } \\
\text { (ppm) }\end{array}$ \\
\hline \multirow[t]{2}{*}{$<1.21$} & 34.4 & 52.3 & 13.3 & Solid phase of leachate & $(-)$ \\
\hline & & & & Solid residue after leaching & $(-)$ \\
\hline \multirow[t]{2}{*}{$(1.21-1.24)$} & 44.2 & 40.6 & 15.2 & Solid phase of leachate & $(-)$ \\
\hline & & & & Solid residue after leaching & $(-)$ \\
\hline \multirow[t]{2}{*}{$(1.24-1.27)$} & 61.1 & 20.7 & 18.2 & Solid phase of leachate & $(-)$ \\
\hline & & & & Solid residue after leaching & $(-)$ \\
\hline \multirow[t]{2}{*}{$(1.27-1.33)$} & 67.9 & 7.4 & 24.7 & Solid phase of leachate & 14.5 \\
\hline & & & & Solid residue after leaching & 3.6 \\
\hline \multirow[t]{2}{*}{$(1.33-1.40)$} & 65.5 & 9.8 & 24.7 & Solid phase of leachate & $(-)$ \\
\hline & & & & Solid residue after leaching & $(-)$ \\
\hline \multirow[t]{2}{*}{$(1.40-1.50)$} & 34.2 & 17.7 & 48.1 & Solid phase of leachate & $(-)$ \\
\hline & & & & Solid residue after leaching & $(-)$ \\
\hline \multirow[t]{2}{*}{$>1.50$} & 27.4 & 20.8 & 51.8 & Solid phase of leachate & $(-)$ \\
\hline & & & & Solid residue after leaching & 3.6 \\
\hline
\end{tabular}

Table 7. Maceral composition of vitrinite in individual fractions from Dukla coal. Telinite, collotelinite, corpogelinite and gelinite contents were negligible.

\begin{tabular}{cccc}
\hline Fraction $\left(\mathrm{g} / \mathrm{cm}^{3}\right)$ & Vitrinite & Collotellinite (vol. \%) & Vitrodetrinite \\
\hline$<1.21$ & 34.4 & 31.3 & 1.1 \\
$(1.21-1.24)$ & 44.2 & 43.2 & 1.0 \\
$(1.24-1.27)$ & 61.1 & 59.6 & 1.5 \\
$(1.27-1.33)$ & 67.9 & 66.7 & 1.2 \\
$(1.33-1.40)$ & 65.5 & 64.0 & 1.5 \\
$(1.40-1.50)$ & 34.2 & 32.3 & 1.9 \\
$>1.50$ & 27.4 & 24.8 & 2.6 \\
\hline
\end{tabular}

vitrinite macerals in order to identify the maceral in which $\mathrm{Al}$ complexes were concentrated. It was found that in the considered fraction completely predominated collotelinite; vitrodetrinite was in the minority, and content of telinite, collodetrinite, corpogelinite and gelinite was negligible (Table 7). 
As the data in Table 7 show, the $1.27-1.33 \mathrm{~g} / \mathrm{cm}^{3}$ fraction contained 67 vol\% collotellinite. Therefore, it could be suggested that the $\mathrm{Al}$ complexes in question were concentrated mainly in collotelinite, representing the gelified and homogenous vitrinite constituent.

As mentioned above, the CSA lignite (ash content $4.10 \mathrm{wt} \%$, Table 2) was also leached with 2-methoxyethanol and resulting solid phase from leachate and solid residue after leaching analyzed (Table 4). Solid phase from leachate exhibited a signal at $14.6 \mathrm{ppm}$, attributed to TTA according to Table 1; solid residue after leaching had the signal at $3.4 \mathrm{ppm}$, attributed to THDA (Table 1), because of low ash content of examined lignite. Moreover, in the mineral composition dominated quartz, gypsum and goethite; $\mathrm{Al}$ minerals were in the minority in this case (Table 2). Practically the same results were achieved when leaching the CSA lignite with $\mathrm{CCl}_{4}$. The solid phase from leachate exhibited a signal at $13.6 \mathrm{ppm}$, solid residue after leaching a signal at $3.5 \mathrm{ppm}$.

\subsection{Formation of the Al Complexes in Coal}

From the above findings, the possible formation of the complexes in question can be deduced. It is fairly certain that primordial plant material contained $\mathrm{Al}$ and that it existed in a complex form, possibly as the $\mathrm{Al}(\mathrm{OH})_{3}\left(\mathrm{H}_{2} \mathrm{O}\right)_{3}$ found in xylite. The long term reactions of this or a similar Al complex with the precursors of coal organic matter as polyphenols and phenols gradually led to the $\mathrm{Al}$ complexes found in coal. Another possibility for these complexes formation arises from the hexa-coordination of $\mathrm{Al}$ to $\mathrm{O}$ in complex species detected. It seems that these compounds can originate from a gibbsite layer in kaolinite, which occurs frequently in coal and lignite. It is well known that an outstanding property of dispersed kaolinite particles is delamination into individual silicate and gibbsite layers [61] [62]. This delamination to octahedral gibbsite and tetrahedral silicate layers preceded the formation of the Al complexes. Regarding the clay-organic interactions [33] it can be suggested that the subsequent reactions of gibbsite with phenols in a waterlogged environment led to the Al complexes in coal, notably in collotelinite.

\section{Conclusion}

Different low ash bituminous coals, lignites and altered coals, as well as gagatite and xylite were analyzed using solid state ${ }^{27} \mathrm{Al}$ MAS NMR; in the spectra, the significant peak at chemical shift at 3.5 - 4 ppm corresponding to a triaquo-hydroxo-diphenoxido-Aluminum(III) complex was found. In the case of anthracites, some bituminous coals, and lignite from Northern Bohemian Basin, the significant peak at chemical shift at 13.5 - 15 ppm corresponding to triaquo-triphenoxido-Aluminum(III) or an Al-catechin complex was observed. These findings, together with petrological analysis, indicate that at least two different Al complexes occur in coal, while they are concentrated in vitrinite, notably collotelinite. Further, the spectra of thermally altered coal from the Upper Silesian Basin showed a chemical shift at $72 \mathrm{ppm}$, showing that a structure with aluminum tetra-coordinated with oxygen was formed during thermal alteration. It can be suggested that the $\mathrm{Al}$ complexes in coal were formed via long term reactions of $\mathrm{Al}$ complex/complexes in primordial plants with polyphenols and phenols (precursors of coal organic matter) or by reactions of gibbsite with phenols in a waterlogged environment. The thermal stability of these $\mathrm{Al}$ complexes is not too high.

\section{Acknowledgements}

This work was supported by the Long-term project for the conceptual development of the research organization No. RVO 67985891.

\section{References}

[1] Howarth, O.W., Ratcliffe, G.S. and Burchill, P. (1987) Solid-State Nuclear Magnetic Resonance Studies of Sodium and Aluminium in Coal. Fuel, 66, 34-39. http://dx.doi.org/10.1016/0016-2361(87)90208-0

[2] Komarneni, S. (1989) Mechanisms of Palygorskite and Sepiolite Alteration as Deduced from Solid-State ${ }^{27} \mathrm{Al}$ and ${ }^{29} \mathrm{Si}$ Nuclear Magnetic Resonance Spectroscopy. Clays and Clay Minerals, 37, 469-473. http://dx.doi.org/10.1346/CCMN.1989.0370512

[3] Thompson, A.R. and Botto, R.E. (2001) NMR of Layered Silicates in Argonne Coals and Geochemical Implications. Energy \& Fuels, 15, 176-181. http://dx.doi.org/10.1021/ef000195w

[4] Straka, P. (2007) Aluminium Complex in Coal. Acta Geodynamica et Geomaterialia, 4, 67-74. 
[5] Shriver, D.F. and Atkins, P.W. (1999) Inorganic Chemistry. 3rd Edition, Oxford University Press, Oxford.

[6] Gažo, J. (1981) General and Inorganic Chemistry. 3rd Edition, Alfa, Bratislava, Slovakia.

[7] Kubicky, J.D., Itoh, M.J., Schroeter, L.M. and Apitz, S.E. (1997) Bonding Mechanisms of Salicylic Acid Adsorbed onto Illite Clay: An ATR-FTIR and Molecular Orbital Study. Environmental Science \& Technology, 31, 1151-1156. http://dx.doi.org/10.1021/es960663+

[8] Nagata, T., Hayatsu, M. and Kosuge, N. (1992) Identification of Aluminium Forms in Tea Leaves by ${ }^{27} \mathrm{Al}$ NMR. Phytochemistry, 31, 1215-1218. http://dx.doi.org/10.1016/0031-9422(92)80263-E

[9] Violante, A., Arienzo, M., Sannino, F., Colombo, C., Piccolo, A. and Gianfreda, L. (1999) Formation and Characterization of OH-Al-Humate-Montmorillonite. Organic Geochemistry, 30, 461-468. http://dx.doi.org/10.1016/S0146-6380(99)00031-5

[10] Bouška, V., Pešek, J. and Sýkorová, I. (2000) Probable Modes of Occurrence of Chemical Elements in Coal. Acta Montana Series B, 117, 53-90.

[11] Klika, Z. and Kolomazník, I. (2000) New Concept for the Calculation of the Trace Element Affinity in Coal. Fuel, 79, 659-670. http://dx.doi.org/10.1016/S0016-2361(99)00187-8

[12] Liu, C. and Huang, P.M. (2002) Role of Hydroxyl-Aluminosilicate Ions (Proto-Imogolite Sol) in the Formation of Humic Substances. Organic Geochemistry, 33, 295-305. http://dx.doi.org/10.1016/S0146-6380(01)00161-9

[13] Jehlička, J. and Edwards, H.G.M. (2008) Raman Spectroscopy as a Tool for the Non-Destructive Identification of Organic Minerals in the Geological Record. Organic Geochemistry, 39, 371-386. http://dx.doi.org/10.1016/j.orggeochem.2008.01.005

[14] Straka, P. (2010) Formation of Tetra-Coordinated Aluminum in the Low Temperature Ashes. Advances in Science and Technology, 69, 129-134. http://dx.doi.org/10.4028/www.scientific.net/ast.69.129

[15] Straka, P. (2010) Behavior of Aluminium Complexes in the Altered Coal and Low Temperature Coal Ashes. Acta Geodynamica et Geomaterialia, 7, 461-467.

[16] Dědeček, J., Sklenak, S., Li, Ch., Gao, F., Brus, J., Zhu, Q. and Tatsumi, T. (2009) Effect of Al/Si Substitutions and Silanol Nests on the Local Geometry of Si and Al Framework Sites in Silicone-Rich Zeolites: A Combined High Resolution ${ }^{27} \mathrm{Al}$ and ${ }^{29} \mathrm{Si}$ NMR and Density Functional Theory/Molecular Mechanics Study. The Journal of Physical Chemistry C, 113, 14454-14466. http://dx.doi.org/10.1021/jp9042232

[17] Dědeček, J., Sklenak, S., Li, Ch., Wichterlová, B., Gábová, V., Brus, J., Sierka, M. and Sauer, J. (2009) Effect of Al$\mathrm{Si}-\mathrm{Al}$ and Al-Si-Si-Al Pairs in the ZSM-5 Zeolite Framework on the ${ }^{27} \mathrm{Al}$ NMR Spectra. A Combined High-Resolution ${ }^{27} \mathrm{Al}$ NMR and DFT/MM Study. The Journal of Physical Chemistry C, 113, 1447-1458. http://dx.doi.org/10.1021/jp8068333

[18] Smith, M.E. and van Eck, E.R.H. (1999) Recent Advantages in Experimental Solid State NMR Methodology for HalfInteger Spin Quadrupolar Nuclei. Progress in Nuclear Magnetic Resonance Spectroscopy, 34, 159-201. http://dx.doi.org/10.1016/S0079-6565(98)00028-4

[19] MacKenzie, K.J.D. and Smith, M.E. (2002) Multinuclear Solid-State NMR of Inorganic Materials. Pergamon, Amsterdam.

[20] Freitas, J.C.C., Schettino Jr., M.A., Emmerich, F.G., Wong, A. and Smith, M.E. (2007) A Multiple-Field ${ }^{23}$ Na NMR Study of Sodium Species in Porous Carbons. Solid State Nuclear Magnetic Resonance, 32, 109-117. http://dx.doi.org/10.1016/j.ssnmr.2007.10.002

[21] Kirkpatrick, R.J. (1988) MAS NMR Spectroscopy of Minerals and Glasses. In: Hawthorne, F.C., Ed., Spectroscopic Methods in Mineralogy and Geology, Reviews in Mineralogy Series, Vol. 18, Mineralogical Society of America, Washington DC.

[22] Kanehashi, K. and Saito, K. (2004) First Application of ${ }^{27}$ Al Multiple Quantum Magic-Angle Spinning Nuclear Magnetic Resonance at 16.4 T to Inorganic Matter in Natural Coals. Energy \& Fuels, 18, 1732-1737. http://dx.doi.org/10.1021/ef040029e

[23] Burchil, P., Howarth, O.W. and Sword, B.J. (1991) MAS n.m.r. Studies of Inorganic Elements in Coal and Combustion Residues. Fuel, 70, 361-366. http://dx.doi.org/10.1016/0016-2361(91)90123-R

[24] Straka, P. and Klika, Z. (2006) Identification of Aluminium Complexes in Coal by NMR Spectroscopy of Solid State. Chemické Listy, 100, 363-367.

[25] Pešek, J. and Sýkorová, I. (2006) A Review of the Timing of Coalification in the Light of Coal Seam Erosion, Clastic Dykes and Coal Clasts. International Journal of Coal Geology, 66, 13-34. http://dx.doi.org/10.1016/j.coal.2005.05.010

[26] Wittbrodt, J.M. (1999) Investigations of Thermochemistry and Reactivity Using ab Initio Molecular Orbital Methods. Abstract. Dissertation, Wayne State University, Michigan. 
[27] Chen, Y.M., Wang, M.K. and Huang P.M. (2006) Catechin Transformation as Influenced by Aluminum. Journal of Agricultural and Food Chemistry, 54, 212-218. http://dx.doi.org/10.1021/jf051926z

[28] Langier-Kuzmiarowa, A. (2002) Thermal Analysis of Organo-Clay Complexes. In: Yariv, S. and Cross, H., Eds., Organo-Clay Complexes, Marcel Dekker, Inc., New York.

[29] Zachariáš, J. and Pešek, J. (2011) Fluid Inclusion Study of Carbonate-Dominated Veinlets from Coal Seams and Rocks of the Central and West Bohemian Basins, Czech Republic. Acta Geodynamica et Geomaterialia, 8, 133-143.

[30] Rosca, I., Cailean, A., Sutiman, D., Rusu, I., Sirgie, I. and Dumitriu, E. (1997) Thermal Stability of Some Aluminium Chelate Complexes. Thermochimica Acta, 303, 1-3. http://dx.doi.org/10.1016/S0040-6031(96)03108-5

[31] Bouška, V. (1981) Geochemistry. Academia, Prague.

[32] Sinkó, K., Mezei, R., Rohonczy, J. and Fratzl, P. (1999) Gel Structures Containing Al(III). Langmuir, 15, $6631-6636$. http://dx.doi.org/10.1021/la980686x

[33] Ruiz-Hitzky, E., Aranda, P. and Serratosa, J.M. (2004) Clay-Organic Interactions: Organo-Clays Complexes and Polymer-Clay Nanocomposites. In: Auerbach, S.M., Carrado, K.A. and Dutta, P.K., Eds., Handbook of Layered Materials, Taylor \& Francis Group, Boca Raton, 91-154.

[34] Thomas, L. (2007) Coal Geology. John Wiley \& Sons Ltd., Chichester.

[35] Zubková, H. (2003) Chemical Structure of Bituminous Coal Macerals. Ph.D. Thesis, Institute of Chemical Technology, Prague.

[36] Samaras, P., Diamadopoulos, E. and Sakellaropoulos, G.P. (1991) The Effect of Demineralization on Lignite Activation. Carbon, 29, 1181-1190. http://dx.doi.org/10.1016/0008-6223(91)90036-I

[37] Taylor, G.H., Teichmüller, M., Davis, A., Diessel, C.F.K., Littke, R. and Robert, P. (1998) Organic Petrology. Gebrüder Borntraeger, Berlin-Stuttgart, 335-428.

[38] ICCP (1998) The New Vitrinite Classification (ICCP System 1994). Fuel, 77, 349-358. http://dx.doi.org/10.1016/S0016-2361(98)80024-0

[39] ICCP (2001) The New Inertinite Classification (ICCP System 1994). Fuel, 80, 459-471. http://dx.doi.org/10.1016/S0016-2361(00)00102-2

[40] Scott, A.C. (2002) Coal Petrology and the Origin of Coal Macerals: A Way Ahead? International Journal of Coal Geology, 50, 119-134. http://dx.doi.org/10.1016/S0166-5162(02)00116-7

[41] Sanz, J. (2006) Nuclear Magnetic Resonance Spectroscopy. In: Bergaya, F., Theng, B.K.G. and Lagaly, G., Eds., Handbook of Clay Science, 1st Edition, Elsevier, Amsterdam, 919-938. http://dx.doi.org/10.1016/S1572-4352(05)01033-0

[42] Ildefonse, P., Cabaret, D., Sainctavit, P., Galas, G., Frank, A.-M. and Lagarde, P. (1998) Aluminium X-Ray Absorption Near Edge Structure in Model Compounds and Earth's Surface Minerals. Physics and Chemistry of Minerals, 25, 112-121. http://dx.doi.org/10.1007/s002690050093

[43] Lewis, J. and Schwarzenbach, D. (1982) Electric Field Gradients and Charge Density in Corundum, $\alpha-\mathrm{Al}_{2} \mathrm{O}_{3}$. Acta Crystallographica Section A, 38, 733-739. http://dx.doi.org/10.1107/S0567739482001478

[44] Newham, R.E. and de Haan, Y.M. (1962) Refinement of the $\alpha-\mathrm{Al}_{2} \mathrm{O}_{3}, \mathrm{Ti}_{2} \mathrm{O}_{3}, \mathrm{~V}_{2} \mathrm{O}_{3}$ and $\mathrm{Cr}_{2} \mathrm{O}_{3}$ Structures. Zeitschrift für Krystallographie, 117, 235-237. http://dx.doi.org/10.1524/zkri.1962.117.2-3.235

[45] Saalfeld, H. and Wedde, M. (1974) Refinement of the Crystal Structure of Gibbsite, $\mathrm{Al}(\mathrm{OH})_{3}$. Zeitschrift für Krystallographie, 139, 129-135. http://dx.doi.org/10.1524/zkri.1974.139.1-2.129

[46] Bish, D.L. and von Dreele, R.B. (1989) Rietveld Refinement of Non-Hydrogen Atomic Positions in Kaolinite. Clays Clay Minerals, 37, 289-296. http://dx.doi.org/10.1346/CCMN.1989.0370401

[47] Dopita, et al. (1997) Geology of the Czech Part of the Upper Silesian Basin. Ministry of the Environment of the Czech Republic, Praha.

[48] Pešek, J., Holub, V., Jaroš, J., Malý, L., Martínek, K., Prouza, V., Spudil, J. and Tásler, R. (2001) Late Paleozoic Limnic Basins of the Czech Republic_-Geology and Coal Deposits. Institute of Geology of the Czech Republic, Praha.

[49] Pešek, J. and Sivek, M. (2012) Coal-Bearing Basin and Deposits of Coal and Lignite in the Czech Republic. Czech Geological Survey, Praha.

[50] Bratek K., Bratek, W., Gerus-Piasecka, I., Jasienko, S. and Wilk, P. (2002) Properties and Structure of Different Rank Anthracites. Fuel, 81, 97-108. http://dx.doi.org/10.1016/S0016-2361(01)00120-X

[51] Wang, H.P., Yang, Y.S., Wang, Y.D., Yang, J.L., Jia, J. and Nie, Y.H. (2013) Data-Constrained Modelling of an Anthracite Coal Physical Structure with Multi-Spectrum Synchrotron X-Ray CT. Fuel, 106, 219-225.

http://dx.doi.org/10.1016/j.fuel.2012.11.079 
[52] Lopez, T.R., Goncalves, G.R., de Barcellos Jr., E., Schettino Jr., M.A., Cunha, A.G., Emmerich, F.G. and Freitas, J.C.C. (2015) Solid State ${ }^{27}$ Al NMR and X-Ray Diffraction Study of Alumina-Carbon Composites. Carbon, 93, 751761. http://dx.doi.org/10.1016/j.carbon.2015.06.001

[53] Duxson, P., Fernández-Jimenéz, A., Provis, J.L., Lukey, G.C., Palomo, A. and van Deventer, J.S.J. (2007) Geopolymer Technology: The Current State of the Art. Journal of Materials Science, 42, 2917-2933. http://dx.doi.org/10.1007/s10853-006-0637-z

[54] Hanzlíček, T. and Perná, I. (2011) The Alumina-Silicates in Stabilization Processes in Fluidized Bed Ash. CeramicsSilikáty, 55, 94-99.

[55] Klika, Z. and Kraussová, J. (1993) Properties of Altered Coals Associated with Carboniferous Red Beds in Upper Silesian Coal Basin and Their Tentative Classification. International Journal of Coal Geology, 22, 217-235. http://dx.doi.org/10.1016/0166-5162(93)90027-8

[56] Kurková, M. (2003) Oxidative and Thermally Altered Coals from Red Beds Bodies Region of the Upper Silesian Coal Basin. Ph.D. Thesis, VŠB, Technical University of Ostrava, Ostrava.

[57] Barker, C.E. and Pawlewitz, M.J. (1986) The Correlation of Vitrinite Reflectance with Maximum Temperature in Humic Organic Matter. In: Buntebarth, G. and Stegena, L., Eds., Paleogeothermics, Lecture Notes in Earth Sciences, Vol. 5, Springer, Berlin-Heidelberg, 79-93. http://dx.doi.org/10.1007/bfb0012103

[58] Taylor, G.H., Teichmüller, M., Davis, A., Diessel, C.F.K., Littke, R. and Robert, P. (1998) Organic Petrology. Gebrüder Borntraeger, Berlin-Stuttgart, 149-150.

[59] Zeng, W. and Chen, N. (1997) Thermodynamic Analysis of Thermal Decomposition of Al(OH) $)_{3}$. Journal of Materials Science and Technology, 13, 446.

[60] Putnis, A. (1992) An Introduction to Mineral Sciences. Cambridge University Press, Cambridge, 86-87. http://dx.doi.org/10.1017/cbo9781139170383

[61] Gardolinski, J.E.F.C. and Lagaly, G. (2005) Grafted Organic Derivates of Kaolinite: II. Intercalation of Primary n-Alkylamines and Delamination. Clay Minerals, 40, 547-556. http://dx.doi.org/10.1180/0009855054040191

[62] Valášková, M., Rieder, M., Matějka, V., Čapková, P. and Slíva, A. (2007) Exfoliation/Delamination of Kaolinite by Low-Temperature Washing of Kaolinite-Urea Intercalates. Applied Clay Science, 35, 108-118. http://dx.doi.org/10.1016/j.clay.2006.07.001 